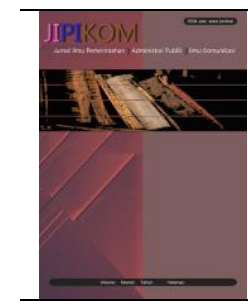

Jurnal Ilmu Pemerintahan, Administrasi Publik dan Ilmu Komunikasi (JIPIKOM), 1(2) 2019: 81-93,

DOI:

Jurnal IImu Pemerintahan, Administrasi Publik dan Ilmu Komunikasi

(JIPIKOM)

Available online http://iurnalmahasiswa.uma.ac.id/index.php/iipikom

Diterima: 11 Agustus 2019; Disetujui: 11 September 2019; Dipublish: 11 Oktober 2019

\title{
Strategi Komunikasi Guru Dalam Menerapkan Pendidikan Karakter terhadap Kelas IX Fullday di SMP Muhammadiyah 7 Medan
}

\section{Teacher Communication Strategies in Applying Character Education to Class IX Fullday in Muhammadiyah 7 Middle School Medan}

\author{
Rahmad Nurdiansyah*, Effiati Juliana Hasibuan \& Novri
}

Program Studi Ilmu Komunikasi, Fakultas Ilmu Sosial Dan Politik, Universitas Medan Area, Indonesia

\section{Abstrak}

Penelitian ini bertujuan untuk mengetahui strategi komunikasi guru dalam menerapkan pendidikan karakter bertauhid, sopan dan santun serta kedisiplinan terhadap siswa kelas ix fullday di SMP Muhammadiyah 7 Medan. Metode penelitian yang digunakan peneliti dalam penelitian ini adalah metode deskriptif dengan analisis kualitatif. Hasil yang diperoleh penelitian bahwa informan pertama yaitu guru menggunakan strategi komunikasi mendekati dengan teori strategi komunikasi Middleton: (1) Karakter bertauhid, strategi komunikasi dalam menerapkan pendidikan karakter bertauhid, komunikator dengan memperhatikan kredibilitas sumber lalu memanajemen kelas dengan cara menarik perhatian siswa dengan mengucapkan salam dan menanyakan keadaan siswa, pesan yang disampaikan yaitu materi tauhid rububiyah, uluhiyah dan al asma' was shifat dijelaskan secara verbal dan non verbal menggunakan bahasa Indonesia baku dan istilah-istilah bahasa terkini; (2) Karakter sopan dan santun, strategi komunikasi dalam menerapkan pendidikan karakter sopan dan santun dengan memperhatikan kredibilitas sumber, memanajemen kelas mendapatkan perhatian siswa dengan memanggil dua atau lebih siswa kedepan kelas untuk memperagakan bentuk interaksi karakter sopan dan santun yang memiliki unsur kelucuan, pesan yang disampaikan; (3) Karakter kedisiplinan, strategi komunikasi dalam menerapkan pendidikan karakter kedisiplinan yaitu komunikator memperhatikan kredibilitas sumber, kemudian mendapatkan perhatian siswa dengan cara melakukan tanya jawab terdapat unsur candaan tentang bentuk kedisiplinan aktivitas sehari-hari yang baik bermanfaat maupun tidak.

Kata Kunci: Strategi Komunikasi, Penerapan, Pendidikan Karakter

\section{Abstract}

This study aims to determine the teacher's communication strategy in implementing character education, monotheism, courtesy and courtesy as well as discipline toward students of class fullday in SMP Muhammadiyah 7 Medan. The research method used by researchers in this research is descriptive method with qualitative analysis. The results obtained by the study that the first informant is the teacher uses a communication strategy approaching the Middleton communication strategy theory: (1) Tawheed character, communication strategies in implementing tawheed character education, communicators by taking into account the credibility of the source and then managing the class by attracting the attention of students by saying greetings and ask the students 'situation, the message conveyed is the material of monotheism rububiyah, uluhiyah and al asma' was shifat explained verbally and nonverbally using standard Indonesian and the latest language terms; (2) polite and polite characters, communication strategies in implementing polite and polite character education by paying attention to the credibility of the source, managing the class get the attention of students by calling two or more students to the front of the class to demonstrate the form of interaction of polite and polite characters that have an element of cuteness, a message that be delivered; (3) Discipline character, communication strategies in implementing disciplinary character education that is communicators pay attention to the credibility of the source, then get the attention of students by conducting questions and answers there are elements of jokes about the form of discipline of daily activities that are both useful or not.

Keywords: Communication Strategies, Implementation, Character Education

How to Cite: Nurdiansyah, Rahmad. Hasibuan, Effiati Juliana. \& Novri. (2019). Strategi Komunikasi Guru Dalam Menerapkan Pendidikan Karakter Terhadap Kelas IX Fullday Di SMP Muhammadiyah 7 Medan. Jurnal Ilmu Pemerintahan, Administrasi Publik dan Ilmu Komunikasi (JIPIKOM), 1(2) 2019: 81-93,

*E-mail: rahmadnurdiansyah@gmail.com

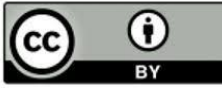

This work is licensed under a Creative Commons Attribution 4.0 


\section{PENDAHULUAN}

Pentingnya pendidikan karakter di sekolah merupakan suatu kegiatan pembelajaran bagi anak yang masih memiliki karakter/sifat dasar yang dipengaruhi dan terbentuk dari lingkungan sekitarnya, adat kebiasaan, kehendak diri sendiri, naluri/insting dan keturunannya. Sifat-sifat dasar tersebut dapat berdampak negatif untuk kehidupannya apabila tidak diarahkan berdasarkan nilai-nilai ajaran agama dan nilai kebaikan yang diterapkan di dalam proses kehidupan manusia (Rumapea, 2015; Nasution, 2016; Ramdani, 2018; Hariyani, 2018; Pandapotan, 2019).

Sekolah merupakan suatu wadah bagi anak, yang memiliki tujuan dalam membentuk karakter anak-anak tersebut sebagai generasi penerus bangsa, menjadi individu-individu yang bertingkah laku baik, jujur, bertanggung jawab, menghormati hak orang lain, kerja keras dan menjadi warga negara yang baik. Dalam sistematis sekolah terdapat istilah guru dan siswa. SMP Muhammadiyah 7 Medan memiliki dua bentuk kelas yaitu kelas fullday dan kelas reguler, kelas fullday merupakan kelas yang memiliki program tambahan seperti program bahasa, yaitu bahasa inggris, jepang dan arab, program tahfidz (hafal) Al-Qur'an dan program oliampiade sains, yang memiliki waktu belajar dari jam 07.30-16.00 WIB, sedangkan kelas reguler merupakan kelas yang memiliki program sesuai standar pendidikan nasional dan pendidikan kemuhammadiyahan yang memiliki waktu belajar dari jam 13.00 - 18.00 WIB.

Pada kegiatan mengajar strategi komunikasi sangat diperlukan untuk dapat mempermudah dalam menyampaikan ilmu kepada para siswa. Pentingnya penerapan strategi komunikasi dalam pendidikan karakter di sekolah merupakan suatu cara agar memudahkan para siswa menerima dan memahami isi pesan yang disampaikan oleh guru sebagai komunikator, pada proses belajar mengajar sehingga memberikan bentuk gambaran yang baik bagi siswa dalam membentuk karakter demi terciptanya Sumber Daya Manusia (SDM) yang berkualitas dan berkarakter baik di masa yang akan datang.

Dewasa ini banyak terjadi kasus kekerasan di dunia pendidikan Indonesia. Media berita online Tribun memuat berita mengenai kasus-kasus kekerasan yang dilakukan siswa terhadap guru. Kasus pertama yang menimpa seorang guru kesenian SMA Negeri 1 Torju kabupaten Sampang Jawa Timur, bernama Ahmad Budi Cahyono, yang meninggal akibat pemukulan dari siswa yang ditegur ketika tertidur di kelas, kasus kedua di SMA Negeri 1 Kubu Raya Kalimantan Barat, seorang siswa memukul seorang guru perempuan bernama Rahayu menggunakan kursi dikarenakan siswa tersebut tidak naik kelas, kasus ketiga di SMP 4 Lolak kabupaten Bolmong Sulawesi Utara, seorang kepala sekolah perempuan dianiaya oleh orang tua siswa, karena kepala sekolah menyuruh orang tua siswa tersebut membuat surat pernyataan atas kelakuan anaknya dan masih banyak lagi peristiwa kejahatan yang terjadi pada sektor pendidikan di Indonesia.

Kementrian pendidikan dan kebudayaan (kemendikbud) sebagai penyelenggara di bidang pendidikan serta pengelola kebudayaan di Indonesia. Saat ini telah memiliki program penguatan pendidikan karakter dalam rangka mendukung program revolusi mental yang pertama kali dicetuskan oleh Presiden Sukarno pada peringatan hari kemerdekaan 17 Agustus 1956, program tersebut saat ini diserukan kembali oleh Presiden Joko Widodo yang akrab dipanggil Jokowi sebagai program di masa pemerintahannya. Program revolusi mental yang diserukan Presiden Jokowi bertujuan dapat mengubah kebiasaan lama menjadi kebiasaan baru untuk mewujudkan negara Indonesia yang berdaulat dan berkarakter. Revolusi mental menuntut masyarakat Indonesia agar dapat beradaptasi dengan cepat, mengubah cara berpikir dimanapun kita berada, bersikap mandiri dan menyesuaikan diri di setiap keadaan. 
Berdasarkan pemaparan tersebut, maka peneliti melakukan penelitian dengan tujuan untuk mengetahui strategi komunikasi guru dalam menerapkan Pendidikan karakter bertauhid, sopan dan santun serta kedisiplinan terhadap siswa kelas ix fullday di SMP Muhammadiyah 7 Medan serta mengetahui faktor-faktor apa saja yang menjadi hambatan strategi komunikasi guru dalam menerapkan pendidikan karakter terhadap siswa kelas ix fullday di SMP Muhammadiyah 7 Medan.

Pendapat Larson dan Knapp dalam Afnuhazi (2015) yang mengatakan komunikasi dapat dikatakan efektif apabila suatu pesan dapat diterima, dimengerti serta dipahami sebagaimana yang dimaksud oleh pengirimnya (komunikator) dan pesan yang disampaikan oleh pengirim dapat disetujui oleh penerima (komunikan) sehingga tidak ada hambatan untuk pesan yang dikirim. Berdasarkan pemaparan tersebut dapat disimpulkan komunikasi adalah sebuah proses penyampaian pesan yang berisi informasi oleh seseorang kepada orang lain, baik itu pesan verbal (lisan) dan non verbal (isyarat), dengan menggunakan media sebagai alat pendukung keberhasilan pada proses komunikasi dan akan menimbulkan efek yang diharapkan dari terciptanya komunikasi efektif yang telah dilakukan.

Strategi pada hakikatnya adalah perencanaan dan manajemen untuk mencapai suatu tujuan, untuk mencapai suatu tujuan tersebut strategi harus mampu menunjukkan bagaimana operasionalnya secara taktis dan praktis. Dalam strategi komunikasi peran seorang komunikator sangat penting sebab strategi komunikasi harus berjalan dengan baik agar komunikator sebagai pelaksana dapat melakukan perubahan strategi bila dalam pelaksanaannya menemui hambatan (Sembiring, 2016; Siahaan, Hendra \& Matondang, 2017). Middleton (Cangara, 2014) menyatakan strategi komunikasi adalah kombinasi yang terbaik dari semua elemen komunikasi mulai dari komunikator, pesan, media, penerima sampai pada pengaruh (efek) yang dirancang untuk mencapai tujuan komunikasi yang optimal. Dalam melancarkan strategi komunikasi guru, menggunakan model perencanaan komunikasi yang dinyatakan oleh Middleton, karena didalamnya terdapat elemen-elemen komunikasi yang memiliki peran dan fungsi masing-masing.

Pentingnya strategi komunikasi yang dinyatakan Middleton di dalam kegiatan belajar mengajar ialah karena pada dasarnya pendidikan adalah komunikasi yang bersifat khusus yang memiliki tujuan untuk meningkatkan pengetahuan seseorang mengenai suatu hal sehingga seseorang tersebut menguasainya. Pada dunia pendidikan terdapat dua komponen manusia yang terdiri dari pengajar (guru) sebagai komunikator dan pelajar (siswa) sebagai komunikan. Dua komponen tersebut melakukan proses komunikasi di dalam kegiatan belajar mengajar. Pada umumnya pendidikan berlangsung secara berencana dan secara tatap muka di dalam kelas, oleh karenanya dibutuhkan suatu bentuk model strategi komunikasi seperti yang dinyatakan oleh Middleton yang didalamnya terdapat kombinasi dari elemen-elemen komunikasi untuk diterapkan oleh guru ketika mengajar di dalam kelas.

Dalam Undang-Undang No. 20 Tahun 2003, Tentang Sistem Pendidikan Nasional, pendidikan diartikan untuk mewujudkan suasana belajar dan proses pembelajaran agar peserta didik secara aktif mengembangkan potensi dirinya agar menjadi manusia yang mulia dan bertaqwa kepada Tuhan Yang Maha Esa, berakhlak mulia, sehat, berilmu, cakap, kreatif, mandiri, menjadi warga negara yang demokratis, serta bertanggung jawab. Hidayatullah (2010) menyatakan bahwa karakter adalah kualitas atau kekuatan mental, moral, akhlak, dan budi pekerti individu yang merupakan kepribadian khusus yang menjadi pendorong, penggerak, serta membedakan dengan individu yang lain. 


\section{METODE PENELITIAN}

Metode penelitian yang digunakan peneliti dalam penelitian ini adalah metode deskriptif dengan analisis kualitatif. Metode penelitian kualitatif menurut Sugiyono (2015) adalah metode penelitian yang berlandaskan pada filsafat postpositivisme, digunakan untuk meneliti pada kondisi objek yang alamiah, (sebagai lawannya adalah eksperimen) dimana peneliti adalah sebagai instrumen kunci, pengambilan sampel sumber data dilakukan secara purposive dan snowball, teknik pengumpulan dengan triangulasi (gabungan), analisis data bersifat induktif/kualitatif dan hasil penelitian kualitatif lebih menekankan makna daripada generalisasi. Penelitian deskriptif ini dimaksudkan untuk memberikan gambaran secara empiric, yaitu berdasarkan pada pengalaman dan pengetahuan dari objek penelitian melalui data yang diperoleh dari observasi, wawancara mendalam serta dokumentasi berdasarkan fakta di lokasi penelitian. Penelitian deskriptif merupakan jenis penelitian yang dapat menghasilkan temuan berbeda yang tidak dapat dicapai dengan menggunakan prosedur kuantifikasi statistik.

Informan dalam penelitian ini adalah guru kemuhammadiyahan kelas ix fullday dan siswa berprestasi pertama sampai ketiga dari masing-masing kelas ix-1 dan ix-2 fullday SMP Muhammadiyah 7 Medan. Penelitian ini difokuskan pada guru kemuhammadiyahan dan siswa yang memiliki prestasi pertama sampai ketiga di kelas ix-1 dan ix-2 fullday di tingkat pendidikan sekolah menengah pertama (SMP) yang sangat berperan penting dalam membentuk karakter anak - anak yang sedang berada di masa peralihan, dari masa anak - anak menuju ke masa remaja, yang mudah terpengaruh akan hal-hal negatif. Siswa kelas ix fullday dianggap representatif dalam memberikan jawaban.

Peneliti memperoleh informasi yang akurat serta dapat bertanggung jawab yang berasal dari lokasi penelitian. Instrumen pendukung pada penelitian ini adalah peran serta peneliti yang terlibat langsung dalam proses penelitian dan menentukan keseluruhan penelitian. Menurut Sugiyono (2014) instrumen penelitian adalah suatu alat yang digunakan mengukur fenomena alam maupun sosial yang diamati. Secara spesifik semua fenomena ini disebut variabel penelitian. Hal ini dilakukan karena peneliti ingin mendapatkan data primer yang lengkap, akurat dan konsisten. Data tersebut diperoleh melalui aplikasi perekam suara di smartphone digunakan untuk wawancara kepada responden, alat-alat tulis untuk mencatat temuan menarik dan sahih dari hasil observasi lapangan serta kamera digital untuk proses pengambilan gambar untuk melengkapi dokumentasi lampiran penelitian dan sebagai keabsahan penelitian.

Menurut Moleong (2014) pengujian kredibilitas sebuah data selain digunakan untuk menyanggah balik apa yang dituduhkan kepada penelitian kualitatif yang mengatakan tidak ilmiah, maka dari itu perlu dilakukan pengujian sebuah data dengan menggunakan metode yang dapat dipercaya dan dipertanggung jawabkan dengan menggunakan teknik triangulasi. Menurut Sugiyono (2015) triangulasi dalam pengujian kredibilitas ini diartikan sebagai pengecekan data dari berbagai sumber dengan berbagai cara, dan berbagai waktu. Dengan demikian terdapat triangulasi sumber, triangulasi teknik pengumpulan data dan waktu. Triangulasi yang digunakan dalam penelitian ini adalah triangulasi sumber, yaitu menyesuaikan data hasil wawancara dan observasi terhadap informan utama, informan pendukung di SMP Muhammadiyah 7 Medan. Ketekunan pengamatan dilakukan dengan teknik pengamatan terhadap kegiatan belajar mengajar yang dilakukan guru di SMP Muhammadiyah 7 Medan, setelah itu data yang 
telah dianalisis oleh peneliti menghasilkan suatu kesimpulan selanjutnya dimintakan kesepakatan dengan tiga sumber data tersebut.

\section{HASIL DAN PEMBAHASAN}

SMP Muhammadiyah 7 Medan merupakan salah satu amal usaha organisasi Muhammadiyah di sektor pendidikan yang mempunyai ciri khas konsep pendidikan karakter tersendiri untuk mendukung program pendidikan nasional dalam mengembangkan potensi siswa seperti keagamaan, akademik, olahraga, seni, sarana prasarana, budaya bersih, unggul dalam kejujuran, kurikuler dan kedisplinan. Konsep pendidikan karakter tersebut berlandaskan pada ciri khas nilai karakter keMuhammadiyahan seperti bertauhid, bekerjasama, tanggung jawab, sopan santun, berkomunikasi yang baik dan disiplin. Nilai-nilai karakter Muhammadiyah tersebut bersumber dari Al-Qur'an dan Sunnah. Karakter bertauhid, sopan santun dan disiplin penting untuk dimiliki setiap individu karena di dalam diri manusia terdapat sifat-sifat yang dapat mengarahkan manusia ke sikap atau perilaku yang buruk, seperti sikap aniaya, bodoh, berkeluh kesah, tergesa-gesa dan jiwa yang mengarah kepada keburukan, oleh karena itu karakter bertauhid, sopan santun dan disiplin akan membuat manusia berpikir secara kontekstual, rasional dan berdasarkan hati nuraninya agar dapat menciptakan pemikiran dan tindakan yang mencerminkan individu tersebut mempunyai nilai hidup yang berharga.

Kegiatan belajar mengajar merupakan suatu proses komunikasi. Dalam ilmu komunikasi, guru berperan sebagai komunikator yang membawa pesan untuk disampaikan kepada komunikan, yaitu para siswa. Komunikator menggunakan media sebagai daya tarik pada saat menyampaikan pesan. Pada proses komunikasi dibutuhkan strategi komunikasi agar pesan yang disampaikan dapat mudah dipahami dan dilaksanakan oleh penerima pesan (komunikan), didalam strategi komunikasi terdapat kombinasi yang baik antara komunikator, pesan, media, penerima sampai pada pengaruh yang dirancang untuk mencapai tujuan komunikasi yang optimal yang dinyatakan oleh Middleton (Cangara, 2014).

Middleton dalam Cangara (2014) menyatakan strategi komunikasi adalah kombinasi yang terbaik dari semua elemen komunikasi mulai dari komunikator, pesan, media, penerima sampai pada pengaruh (efek) yang dirancang untuk mencapai tujuan komunikasi yang optimal. Dalam melancarkan strategi komunikasi guru, lebih baik menggunakan model perencanaan komunikasi yang dinyatakan oleh Middleton, karena didalamnya terdapat elemen-elemen komunikasi yang memiliki peran dan fungsi masing-masing. Berikut ini penjelasan singkat elemen-elemen komunikasi, yaitu: (1) Komunikator, merupakan pihak yang menyampaikan dan mengirim pesan kepada penerima, bertindak sebagai sumber utama yang membawa dan memanajemen pesan untuk dikirim kepada penerima, komunikator memiliki daya tarik dan kredibilitas, yaitu faktor yang menyebabkan keberhasilan komunikasi;

(2) Pesan, pernyataan yang didalamnya terdapat suatu informasi untuk disampaikan komunikator (pengirim) kepada penerima, dalam penerapannnya menggunakan teknik informasi, persuasi dan instruksi sesuai dengan tujuan pesan komunikasi tersebut, pernyataan dapat berupa verbal (tertulis dan lisan) maupun non verbal (isyarat) yang dapat dimengerti oleh penerima; (3) Media, alat yang digunakan oleh sumber (komunikator) untuk memindahkan dan mendukung pesan yang disampaikan kepada penerima, komunikator dapat memilih salah satu atau gabungan dari berbagai media untuk mencapai sasaran komunikasi, seperti media massa televisi, radio, surat kabar dan internet serta media alternatif lainnya seperti organisasi masyarakat dan rumah ibadah; (4) Penerima, pihak yang menjadi sasaran 
komunikator dalam menyampaikan pesan, penerima memiliki kerangka referensi yang berbeda-beda dalam dirinya, seperti ideologi, pendidikan, norma hidup, status sosial, pengalaman dan gaya hidup, dalam proses komunikasi penerima biasa disebut sebagai komunikan; (5) Pengaruh (efek), sebuah pemikiran, perasaan dan perlakuan yang timbul sebelum dan sesudah penerima (komunikan) menerima pesan.

Pesan yang disampaikan dapat mempengaruhi, merubah dan menguatkan keyakinan, sikap, pengetahuan dan tingkah laku seseorang akibat dari penerimaan pesan, terdapat 3 bentuk pengaruh (efek) yang mendukung dalam melihat keberhasilan pengaruh pesan yang disampaikan sumber di dalam komunikasi, yaitu : (a) Kognitif adalah pesan yang disampaikan memberikan informasi baru bagi penerimanya, informasi tersebut berupa data atau gambaran dalam memperoleh pengetahuan baru yang awalnya tidak diketahui; (b) Afektif berkaitan dengan perasaan atau emosi, ketika pesan yang disampaikan komunikator menimbulkan perasaan atau merubah perasaan komunikan; (c) Konatif berkaitan dengan perilaku dan tindakan, efek konatif disebut juga sebagai efek behavioral, merupakan efek yang timbul dari perpaduan efek kognitif dan afektif, misalnya seseorang menonton berita bencana alam maka timbul rasa iba untuk membantu korban bencana tersebut, kemudian dia mewujudkannya dengan tindakan turut memberikan sumbangan terhadap korban bencana tersebut.

Data yang diperoleh selama penelitian melalui observasi, wawancara dan dokumentasi akan disajikan dengan menggunakan metode kualitatif kemudian data dianalisis dengan teknik deskriptif. Pada bagian ini akan dideskripsikan data hasil penelitian yang telah peneliti peroleh selama dilapangan berdasarkan teori strategi komunikasi yang dinyatakan oleh Middleton, peneliti memaparkan mengenai pendidikan karakter bertauhid, sopan santun dan kedisiplinan serta melihat tanggapan informan terhadap pemahaman pesan dan kasus kekerasan yang dilakukan murid terhadap guru yang terjadi di Indonesia. Berikut adalah hasil kerja keras peneliti yang dibantu oleh berbagai informan untuk mencari jawaban dari tujuan penelitian ini.

Karakter Bertauhid. Dalam kegiatan komunikasi, komunikator mempunyai tujuan untuk menyampaikan pesan dan menciptakan umpan balik (feedback) dari komunikan sesuai dengan harapannya, ketika melakukan proses berkomunikasi, pesan yang ingin disampaikan komunikator tidak selalu berjalan dengan baik tetapi dapat berjalan dengan baik sebagaimana mestinya dengan mempersiapkan rencana atau strategi yang mendukung keberhasilan komunikasi tersebut, oleh karenanya strategi komunikasi dibutuhkan, peneliti mengambil satu bentuk teori yang dianggap sesuai dengan judul penelitian yaitu model perencanaan komunikasi. Berikut ini pemaparan strategi komunikasi Middleton dalam menerapkan pendidikan karakter bertauhid.

Komunikator. Informan kedua sampai ketujuh sepakat berpendapat dalam hal kredibilitas informan pertama memiliki latar belakang sebagai seorang yang telah lama aktif berorganisasi di pimpinan cabang Muhammadiyah Medan Perjuangan dan telah menempuh pendidikan keguruan, tentu dipercaya membawa materi pendidikan karakter Kemuhammadiyahan khususnya karakter tauhid sehingga siswa otomatis mempercayainya sebagai seorang guru (komunikator) yang dapat mengajarkan pengetahuan baru. Menurut informan pertama untuk memanajemen kelas strategi komunikasi yang dilakukan adalah menarik perhatian para siswa ketika menerapkan karakter bertauhid dengan mengucapkan salam lalu menanyakan keadaan siswa terlebih dahulu, setelah mengetahui kondisi fisik dan psikis ( $m o o d$ ) siswa kemudian mengisahkan sedikit anekdot lalu menjelaskan contoh karakter bertauhid didalam proses kehidupan yang didalamnya berisikan cerita menarik dengan mempertahankan alur cerita yang masih terkait dengan karakter bertauhid tersebut. Tujuannya untuk mengontrol keadaan 
kelas karena perhatian siswa telah didapat dan menghindari susasana kelas yang jenuh sehingga dapat membangkitkan semangat siswa kembali untuk memahami materi bertauhid secara menyeluruh.

Pesan. Menurut informan pertama materi karakter bertauhid yang diajarkan kepada siswa adalah tauhid rububiyah, uluhiyah, dan al asma' was shifat, ketiga bentuk tauhid tersebut dijelaskan secara verbal dan nonverbal sebagai bentuk kombinasi antara lisan dan isyarat, menggunakan bahasa Indonesia yang baku serta istilah-istilah bahasa terkini yang lagi populer dengan teknik informasi yaitu materi karakter tauhid sebagai informasi pengetahuan baru bagi siswa lalu persuasi yaitu memberikan gambaran contoh dampak dan manfaat agar dapat membuktikan karakter tauhid tersebut memiliki banyak manfaat apabila dipahami kemudian diterapkan dan instruksi yaitu memberikan tugas individu maupun kelompok seperti memberikan soal-soal pengertian, contoh dan penerapan karakter bertauhid yang telah dilakukan dalam kesehariannya, membuat presentasi kelompok agar siswa dapat berinteraksi membahas materi bertauhid secara terbuka dan mendalam. Hal tersebut bertujuan menguatkan, melatih dan mengetahui sejauh mana pehaman siswa menerima ilmu pengetahuan yang disampaikan sebagai bentuk keberhasilan komunikasi yang dilakukan oleh guru sebagai komunikator.

Media. Menurut informan pertama ketika menjelaskan materi bertauhid kepada siswa didukung dengan menggunakan media perangkat keras dan lunak seperti proyektor yang menampilkan slide materi, gambar, video dan cuplikan film yang terkait dengan materi karakter bertauhid, lalu buku, papan tulis untuk menjelaskan hal yang disimpulkan. Media-media tersebut bertujuan membuat pesan menjadi menarik dan mendukung interaksi terhadap siswa untuk merangsang pikiran, perasaan, perhatian, kemampuan yang dimiliki siswa.

Penerima. Menurut informan pertama karena siswa masih sebagai pelajar di satu sekolah yang memiliki satu visi dan misi tentang Islam, siswa sebagai pihak penerima pesan tidak memiliki kerangka referensi yang berbeda, karena tugas siswa masih hanya mengikuti dan memahami pelajaran yang diprogramkan sesuai tingkatan pendidikannya dengan begitu komunikator dengan mudah merencanakan dan memanajemen strategi komunikasi yang akan diterapkan ketika menyampaikan materi tentang karakter bertauhid. Menurut informan kedua sampai ketujuh, para siswa sebagai pihak komunikan sepakat berpendapat bahwa menyukai cara penjelasan terhadap materi karakter bertauhid yang dilakukan guru karena didalamnya terdapat unsur singkat, santai, lucu dan tetap fokus pada materi karakter bertauhid, menciptakan suasana belajar menarik untuk diikuti sehingga dapat menghindari terciptanya kejenuhan suasana kelas yang dapat mempengaruhi keadaan siswa dalam memahami ilmu pengetahuan. Berdasarkan hal tersebut, informan kedua sampai ketujuh menyatakan paham dari aspek pengertian karakter bertauhid dan menganggap karakter tersebut berperan penting dapat mengontrol pola pikir dan perilaku seseorang menjadi baik karena telah memahami dan memiliki karakter bertauhid.

Pengaruh (efek). Menurut informan pertama dalam upaya mengetahui siswa telah menerapkan karakter bertauhid pada kesehariannya, yaitu dengan cara memanggil dua siswa kedepan kelas untuk mencontohkan bagaimana bentuk penerapan bertauhid yang telah diterapkan dan memberikan pertanyaan yang akan menimbulkan jawaban berupa pernyataan siswa telah menerapkan tauhid pada kesehariannya. Hal ini bertujuan menciptakan bentuk jawaban bahwa siswa telah memahami dan melatih jiwa sosial mereka ketika berinteraksi dengan orang disekitarnya. Menurut informan kedua sampai 
ketujuh pendidikan karakter bertauhid merupakan bentuk efek kognitif karena mempunyai konsep pengetahuan baru dari pengelompokan peribadahan dalam ajaran islam yang tidak pernah diketahui sebelumnya, setelah mengetahui karakter bertauhid, informan kedua sampai ketujuh berpendapat karakter tersebut mempengaruhi pemikiran, menguatkan keyakinan ajaran islam serta dapat merubah tingkah laku mereka menjadi lebih baik kedepannya. Dapat diketahui bahwa pendidikan karakter bertauhid menciptakan efek konatif karena penerima merasa pesan tersebut mempengaruhi tingkah laku sehingga baik untuk dipahami.

\section{Karakter Sopan dan Santun}

Komunikator. Informan kedua sampai ketujuh telah sepakat dalam hal kredibilitas, informan pertama sebagai guru yang memiliki latar belakang aktif berorganisasi di Muhammadiyah, seorang komunikator yang tugasnya mendidik siswa sebagai komunikan tentu tidak diragukan dan dipercaya karena pesan yang disampaikan bisa diterima dan tidak menimbulkan pertentangan pemahaman dari pihak organisasi dan komunikan. Menurut informan pertama dalam hal memanajemen kelas, strategi komunikasi yang dilakukan pertama mendapatkan perhatian siswa dengan memanggil dua siswa atau lebih ke depan kelas untuk menciptakan bentuk interaksi menarik yang dapat membuat suasana kelas menjadi interaktif seperti memperagakan bentuk karakter sopan dan santun yang memiliki unsur kelucuan didalamnya. Hal ini bertujuan agar menciptakan suasana kelas penuh semangat sekaligus mempengaruhi fokus perhatian siswa terhadap materi karakter sopan dan santun yang akan dijelaskan selanjutnya

Pesan. Menurut informan pertama materi karakter sopan dan santun yang diajarkan kepada siswa adalah sopan dan santun terhadap diri sendiri serta orang lain, kedua bentuk sopan dan santun tersebut dijelaskan secara verbal dengan dukungan non verbal dalam waktu bersamaan, menggunakan bahasa Indonesia baku dipadukan dengan istilah yang sedang populer, dijelaskan dengan teknik informasi yaitu sebagai pengetahuan yang bersifat memperluas pengetahuan sebelumnya, kemudian persuasi yaitu menjelaskan manfaat memahami sopan dan santun pada diri sendiri dan orang lain akan membuat seseorang dapat mengendalikan pola pikir, emosi dan moral sehingga menimbulkan dampak positif bagi diri sendiri dan lingkungan sekitarnya, memberikan manfaat dalam membentuk kepribadian yang menuntun seseorang pada jalan kesuksesan.

Terakhir berbentuk instruksi yaitu memberikan tugas individu seperti menjawab soal-soal yang terkait dengan materi karakter sopan santun tersebut dan berkelompok seperti membuat siswa mempresentasikan materi sopan dan santun untuk menciptakan interaksi antar siswa dalam membahas sopan santun lebih lanjut dari opini yang berbeda, lalu menciptakan sebuah drama berkelompok di depan kelas yang menampilkan bentuk contoh penerapan karakter sopan dan santun pada aktivitas sehari-hari. Hal ini bertujuan memberikan pengaruh pada pemikiran siswa bahwa karakter sopan dan santun memiliki peran dan pengaruh penting dalam bersosial yang dapat menimbulkan manfaat dan kerugian didalam hidup.

Media. Menurut informan pertama untuk membuat pembelajaran lebih optimal ketika menjelaskan materi sopan dan santun dengan menambahkan media sebagai alat pendukung pesan seperti buku, laptop, proyektor menampilkan contoh sopan dan santun ketika menggunakan media sosial Facebook, Instagram dan Whatsapp, slide berisi konten materi sopan dan santun dikombinasikan dengan gambar, foto, video dan film tetap berfokus pada materi sopan dan santun. Penggunaan media- media tersebut 
bertujuan menciptakan pembelajaran efisien dan efektif sehingga dapat menumbuhkan sikap positif siswa terhadap materi dan proses belajar.

Penerima. Menurut informan pertama kerangka referensi komunikan yaitu siswa tidak terlalu dikhawatirkan karena status mereka sebagai pelajar dalam satu sekolah mempunyai fokus yang sama, hal pertama yang perlu diperhatikan adalah keadaan fisik dan psikis siswa pada awal dimulainya pelajaran, apabila mengetahui keadaan tersebut, guru dapat langsung menyesuaikan suasana kelas menjadi interaktif dan menarik untuk diikuti.

Informan kedua sampai ketujuh sepakat berpendapat bahwa menyukai cara penjelasan guru pada materi karakter sopan santun terhadap diri sendiri dan orang lain, karena penjelasan guru melibatkan istilah bahasa terkini yang menjadi daya tarik tersendiri bagi siswa, menciptakan suasana belajar santai dengan tetap memperhatikan kemajuan pembelajaran, kemudian membuat suatu aktivitas dalam suasana belajar seperti presentasi kelompok dan drama yang tetap fokus terhadap materi pendidikan karakter sopan dan santun. Informan kedua sampai ketujuh juga menyatakan telah memahami materi sopan dan santun, menganggap karakter tersebut dapat mengontrol pikiran ketika melakukan tindaka, menimbulkan rasa saling mempercayai satu sama lain dan menciptakan hubungan baik dengan yang muda dan tua serta keharmonisan lingkungan sekitar saling menghargai.

Pengaruh (efek). Menurut informan pertama untuk mengetahui siswa telah menerapkan karakter sopan dan santun pada kesehariannya, yaitu dengan cara merangsang pemikiran siswa melalui pertanyaan dan soal-soal yang memuat contoh penerapan dari karakter sopan dan santun yang telah dilakukan atau belum dilakukan oleh siswa ketika berinteraksi dengan orang lain pada aktivitas kesehariannya, seperti melalui jawaban-jawaban siswa tersebut guru dapat mengetahui apabila siswa telah memahami kemudian menerapkan sopan dan santun dimanapun mereka berada. Hal ini bertujuan memancing siswa untuk memberi jawaban sebagai pernyataan bahwa telah menerapkan karakter sopan dan santun.

Menurut informan kedua sampai ketujuh pendidikan karakter sopan dan santun telah diketahui sebelumnya tetapi hanya sebatas sebagai pengetahuan dasar, lalu pada saat ini pengetahuan karakter sopan dan santun telah diperluas pemahamannya didalam materi pendidikan Kemuhammadiyahan, dapat diketahui efek yang dihasilkan berbentuk kognitif karena memperluas informasi dari pengetahuan sebelumnya. Informan kedua sampai ketujuh sepakat berpendapat bahwa pendidikan karakter sopan santun memberikan pengaruh pada perasaan dan emosi sehingga menganggap karakter tersebut penting untuk dipahami, akan memberikan manfaat membuat seseorang dapat dipercaya, dihargai dan menciptakan hubungan baik bagi lingkungan sekitar. Dapat diketahui bahwa pesan pendidikan karakter sopan santun menciptakan efek lanjutan dari kognitif yaitu konatif, karena penerima merasa pesan tersebut dapat mempengaruhi perasaan dan emosi siswa untuk menerapkan karakter sopan dan santun pada wadah dihidupnya.

\section{Karakter Kedisiplinan}

Komunikator. Informan kedua sampai ketujuh berpendapat pada hal kredibilitas, komunikator dipercaya mampu mengajarkan materi karakter kedisiplinan, karena latar belakang profesi yang memiliki fokus keahlian dalam hal mengajarkan ilmu pengetahuan yang bermanfaat kepada siswa (komunikan) dan kegiatan organisasi Muhammadiyah yang telah diikuti sejak lama. 
Menurut informan pertama strategi komunikasi yang dilakukan dalam memanajemen kelas adalah mendapatkan perhatian siswa, apabila telah didapat, itu berarti suasana kelas dapat dikendalikan oleh guru, kuncinya adalah mendapatkan perhatian siswa, cara yang dilakukan adalah melakukan tanya jawab tentang pengertian karakter disiplin yang dihubungkan dengan bentuk aktivitas keseharian yang baik maupun tidak baik apabila dilakukan dapat bermanfaat untuk diri sendiri dan orang lain yang dibuat menarik mungkin dengan unsur candaan didukung media proyektor yang menampilkan slide berisi presentasi dalam bentuk gambar, video, berita online dan cuplikan film. Hal ini bertujuan mendapatkan fokus perhatian dari siswa pada sesi tersebut agar siswa dapat memiliki gambaran materi kedisiplinan yang akan dibahas lebih luas pada sesi selanjutnya.

Pesan. Menurut informan pertama materi karakter kedisplinan yang diajarkan kepada siswa adalah disiplin dalam waktu, disiplin diri sendiri, disiplin nasional dan manfaat disiplin dijelaskan secara verbal dan didukung bahasa non verbal dalam waktu bersamaan, menggunakan bahasa Indonesia baku melibatkan istilah-istilah bahasa yang sedang populer dikalangan masyarakat khususnya remaja, dijelaskan dengan teknik informasi yaitu sebagai pengetahuan yang bersifat menambah pengetahuan yang sudah ada sebelumnya, lalu persuasi yaitu menjelaskan manfaat memahami karakter kedisiplinan dengan menjelaskan berbagai jenis peraturan dan norma-norma untuk diri sendiri maupun yang berlaku di masyarakat serta dampak yang akan terjadi bagi diri sendiri apabila mentaati dan melanggar peraturan beserta norma tersebut.

Selanjutnya dengan bentuk instruksi yaitu memberikan tugas individu seperti menjawab soal-soal yang menyinggung materi karakter kedisiplinan terutama pada aktivitas sehari-hari, memberi tugas pernyataan telah menerapkan karakter kedisiplinan pada aktivitas sehari-hari yang diketahui oleh orang tua siswa dibuktikan dengan menandatangai tugas tersebut dengan jelas lalu tugas berkelompok yaitu membagi siswa menjadi beberapa kelompok untuk mempresentasikan dan membahas bersama dengan siswa lain bagian-bagian dari materi kedisiplinan yang dipisah untuk menciptakan kesimpulan dari interaksi yang dilakukan siswa di akhir materi yang diajarkan. Hal tersebut bertujuan membuat siswa dapat berpikir untuk dapat mengontrol diri sebelum melakukan tindakan yang dapat merugikan diri sendiri dan mengikuti aturan dan norma yang dibuat demi mengatur kebaikan untuk diri sendiri dan kebaikan untuk orang disekitarnya.

Media. Menurut informan pertama untuk mendukung pembelajaran lebih interaktif, pada saat menjelaskan materi kedisiplinan yaitu dengan menggunakan media sebagai alat pendukung pesan, media yang digunakan seperti buku, laptop, proyektor menampilkan slide yang memuat pengertian kedisiplinan secara menyeluruh dan contoh kedisiplinan pada aktivitas sehari-hari seperti dimulai dari hal kecil tidak membuang sampah sembarangan dikombinasikan dengan gambar, foto, video maupun film dan memuat berita tentang kasus pelanggaran yang bersifat tidak memperdulikan kedisiplinan sehingga menimbulkan kerugian bagi dirinya sendiri dan orang lain di lingkungan sekitarnya. Penggunaan media-media tersebut bertujuan menciptakan pembelajaran yang dapat memperjelas pesan dan informasi, meningkatkan dan mengarahkan perhatian siswa sehingga menimbulkan motivasi belajar. Hal ini bertujuan agar siswa dapat berpikir bahwa setiap tindakan memiliki konsekuensi, oleh karena itu keputusan siswa untuk memahami kedisiplinan akan memberikan gambaran, membuat kehidupan seseorang tertata serta berhati-hati dalam melakukan tindakan dihidupnya. Penerima 
Menurut informan pertama kerangka referensi siswa sebagai komunikan tidak memiliki banyak perbedaan karena siswa masih berstatus sebagai pelajar dalam tingkatan pendidikan di satu sekolah yang sama, hal pertama yang perlu diperhatikan adalah keadaan fisik dan psikis siswa pada awal ketika akan dimulainya pembelajaran, karena keadaan tersebut dapat terpengaruh dari aktivitas yang dilakukan siswa sebelumnya, apabila guru mengetahui keadaan siswa tersebut, guru dapat langsung mengambil langkah dengan menyesuaikan keadaan siswa agar suasana kelas menjadi kondusif sehingga melancarkan pembelajaran.

Informan kedua sampai ketujuh sepakat bahwa menyukai cara penjelasan guru ketika menerapkan materi karakter kedisiplinan dalam waktu, pada diri sendiri dan nasional kepada siswa. Informan kedua sampai ketujuh sebagai pihak siswa menyukai hal tersebut karena penjelasan guru menggunakan bahasa yang mudah dimengerti, dikombinasikan dengan istilah bahasa terkini yang populer khususnya dikalangan remaja menjadi daya tarik tersendiri bagi siswa, kemudian penggunaan media menampilkan informasi baru yang dapat membuat siswa membayangkan hal yang akan terjadi dari dampak penerapan karakter disiplin dihidupnya, menciptakan suatu aktivitas interaktif dalam suasana belajar seperti presentasi kelompok dengan tetap memperhatikan kemajuan pembelajaran yang tetap fokus pada materi pendidikan karakter kedisiplinan. Informan kedua sampai ketujuh menyatakan bahwa telah paham pengertian, maksud dan tujuan materi karakter kedisiplinan untuk dipelajari lalu menganggap karakter kedisiplinan sebagai cara untuk dapat menertibkan diri sendiri sehingga tindakan yang dilakukan telah terlatih berdasarkan kedisiplinan dan akan terus berada ruang lingkup kebaikan karena telah memahami dan terbiasa menerapkan kedisiplinan untuk mentaati peraturan dan norma yang berlaku pada diri sendiri, lingkungan sekitar dan bangsa.

Pengaruh (efek). Menurut informan pertama agar dapat mengetahui siswa telah menerapkan karakter kedisiplinan pada aktivitasnya, yaitu dengan cara memberi pertanyaan tentang bentuk aktivitas yang menunjukkan bahwa siswa telah menerapkan kedisiplinan dihidupnya, hal tersebut bertujuan melatih siswa bersikap dan menentukan tindakan berdasarkan nilai kedisiplinan serta dapat membayangkan dan merasakan langsung bentuk keadaan interaksi sosial yang akan dihadapi.

Informan kedua sampai ketujuh berpendapat pendidikan karakter kedisiplinan telah dipelajari sebelumnya tetapi hanya mengetahui karakter kedisiplinan secara mendasar, pada saat ini ketika mempelajari pendidikan Kemuhammadiyahan pengetahuan pendidikan karakter kedisiplinan mendapatkan tambahan pengetahuan baru yang dikembangkan ke dalam berbagai aspek kehidupan yang disesuaikan berdasarkan kebutuhan pada aspek-aspek tersebut. Dapat diketahui efek yang dihasilkan berbentuk kognitif karena karakter kedisiplinan merupakan pengetahuan yang telah diketahui sebelumnya dan mendapatkan tambahan informasi baru sebagai pengetahuan dengan memperluas jangkauannya.

Informan kedua sampai ketujuh sepakat berpendapat bahwa pendidikan karakter kedisiplinan memberikan pengaruh pada perasaan dan emosi sehingga membuat perasaan siswa menganggap karakter kedisiplinan dapat menuntun seseorang menuju jalan kesuksesan karena terbiasa mentaati peraturan yang telah dibuat untuk diri sendiri seperti menertibkan diri sendiri dalam beberapa hal dengan begitu seseorang selanjutnya akan terbiasa mentaati aturan-aturan yang berlaku di masyarakat, suatu daerah dan negara.memberikan manfaat membuat seseorang dapat dipercaya, dapat diketahui bahwa pesan pendidikan karakter kedisiplinan menciptakan efek lanjutan dari 
kognitif dan afektif yaitu konatif, karena penerima merasa pesan tersebut dapat mempengaruhi perasaan dan emosi siswa untuk merubah pengetahuan dasar karakter kedisiplinan sebelumnya, menjadi pengetahuan baru yang diperluas ketika menerapkan karakter kedisiplinan.

\section{SIMPULAN}

Karakter bertauhid, strategi komunikasi guru dalam menerapkan pendidikan karakter bertauhid, komunikator dengan memperhatikan kredibilitas sumber lalu memanajemen kelas dengan cara menarik perhatian siswa dengan mengucapkan salam dan menanyakan keadaan siswa, pesan yang disampaikan yaitu materi tauhid rububiyah, uluhiyah dan al asma' was shifat dijelaskan secara verbal dan nonverbal menggunakan bahasa Indonesia baku dan istilah-istilah bahasa terkini dengan teknik informasi, persuasi dan instruksi, menggunakan media proyektor yang menampilkan slide materi, gambar, video, cuplikan film, buku dan papan tulis, tidak terlalu mengkhawatirkan kerangka referensi penerima karena komunikan masi berstatus sebagai pelajar di sekolah yang sama, menimbulkan pengaruh (efek) konatif pada diri siswa selaku komunikan.

Karakter sopan dan santun, strategi komunikasi guru dalam menerapkan pendidikan karakter sopan dan santun dengan memperhatikan kredibilitas sumber, memanajemen kelas mendapatkan perhatian siswa dengan memanggil dua atau lebih siswa kedepan kelas untuk memperagakan bentuk interaksi karakter sopan dan santun yang memiliki unsur kelucuan, pesan yang disampaikan yaitu materi sopan dan santun terhadap diri sendiri dan orang lain, dijelaskan secara verbal didukung nonverbal menggunakan bahasa Indonesia baku dipadukan istilah bahasa populer dengan teknik informasi, persuasi dan instruksi, didukung dengan media buku, laptop, proyektor menampilkan slide materi dan contoh sopan dan santun di media sosial dikombinasikan dengan gambar, video dan film, menimbulkan pengaruh (efek) konatif didalam diri siswa.

Karakter kedisiplinan, strategi komunikasi guru dalam menerapkan pendidikan karakter kedisiplinan yaitu komunikator memperhatikan kredibilitas sumber, kemudian mendapatkan perhatian siswa dengan cara melakukan tanya jawab terdapat unsur candaan tentang bentuk kedisiplinan aktivitas sehari-hari yang baik bermanfaat maupun tidak, pesan yang disampaikan yaitu materi kedisiplinan dalam waktu, diri sendiri, nasional dan manfaat kedisiplinan, dijelaskan secara verbal didukung nonverbal pada waktu bersamaan dengan teknik informasi, persuasi dan instruksi, menggunakan bahasa Indonesia baku dipadukan dengan istilah bahasa populer dikalangan remaja, kemudian didukung penggunaan media buku, laptop, proyektor menampilkan slide materi kedisiplinan menyeluruh dikombinasikan dengan gambar, video, film dan berita kasus pelanggaran kedisiplinan, sehingga menciptakan efek konatif bagi diri siswa.

\section{DAFTAR PUSTAKA}

Afnuhazi, R. (2015). Komunikasi Terapeutik dalam Keperawatan Jiwa, Yogyakarta: Gosyen Publishing

Bangsa, Surakarta: Yuma Pustaka.

Cangara, H. (2014). Perencanaan dan Strategi Komunikasi, Jakarta: Raja Grafindo Persada

Hariyani, R.S. (2018). Upaya Mewujudkan Pendidikan Karakter Bangsa dalam Proses Kegiatan Belajar Mengajar di Sekolah Menengah Kejuruan Negeri 3 Karang Baru Aceh Tamiang. JUPIIS: Jurnal Pendidikan Ilmu-ilmu Sosial, 11 (1):121-134.

Hidayatullah, Furqon M. (2010). Pendidikan Karakter Membangun Peradaban 
Moleong, L. (2014). Metodologi Penelitian Kualitatif Edisi Revisi, Bandung: PT. Remaja Rosa Karya

Nasution, A.R., (2016), Urgensi Pendidikan Kewarganegaraan sebagai Pendidikan Karakter Bangsa Indonesia melalui Demokrasi, HAM dan Masyarakat Madani, Jurnal Pendidikan Ilmu-Ilmu Sosial, 8 (2) (2016): 201-212.

Pandapotan, S. (2019). Dinamika Pendidikan Karakter dalam Kajian Budaya Dan Psikologi Pendidikan. Journal of Education, Humaniora and Social Sciences (JEHSS). 2 (2): 271-278.

Ramdani, E. (2018). Model Pembelajaran Kontekstual Berbasis Kearifan Lokal sebagai Penguatan Pendidikan Karakter, Jurnal Pendidikan Ilmu-Ilmu Sosial, 10 (1): 1-10.

Rumapea, M.E.M. (2015). Urgensi Pendidikan Karakter d Perguruan Tinggi, Jurnal Pendidikan Ilmu-Ilmu Sosial, 7 (1) (2015): 49-59.

Sembiring, J.P., (2016), Strategi Komunikasi Pemasaran Objek Wisata Gundaling dan Pemandian Air Panas Semangat Gunung, Jurnal Simbolika: Research and Learning in Comunication Study, 2 (1): 134-155

Siahaan, W.C. Hendra, Y. \& Matondang, A (2017). Strategi Komunikasi Pemasaran PT. OPPO Indonesia dalam Meningkatkan Citra Smartphone OPPO. PERSPEKTIF, 6 (1): 8-12.

Sugiyono, (2015). Metode Penelitian Pendidikan, Bandung: Alfabeta

Sugiyono. (2014). Metode Penelitian Kuantitatif, Kualitatif, dan Kombinasi (Mixed Methods), Ed. Sutopo, Bandung: Alfabeta

Undang-Undang No. 20 Tahun 2003, Tentang Sistem Pendidikan Nasional 